\title{
An Extract of Zingiber officinale and Piper retrofractum Combination and Its Effect to Cancer Cell Line
}

\author{
Heny Ekowati, Septiyaningsih and Harwoko \\ Pharmacy Department, Medicine and Health Sciences Faculty, \\ Universitas Jenderal Soedirman, \\ Jl. Dr. Soeparno, Karangwangkal, Purwokerto 53123
}

\begin{abstract}
Chemotherapy may emerge side-effect since it may treat inconveniently the synthesis of nucleic acids and proteins, both cancer cells or normal cells. Plants as a cancer therapy were expected to reduce this toxicity and side effects. Plants which used empirically for cancer therapy was Zingiber officinale cv. Rubrum and Piper retrofractum. This study was conducted to examine the cytotoxic activity of ethanolic extract combination of two plants in HeLa and T47D cell lines. Zingiber officinale cv. Rubrum, Piper retrofractum and mixture (I:I) powdered then macerated with $96 \%$ ethanol for $3 \times 24$ hours. Identification of the constituent that had potential anticancer effect was used TLC with silica GF 254 as stationary phase, cytotoxic activity was examined by yellow MTT assay, then analyzed using probit. Apoptotic assay was performed by immunofluororescence method, using fluorochromes ethidium bromide and acridine orange. The result showed that Zingiber officinale cv. Rubrum contains terpenoids, while Piper retrofractum contains alkaloids substance. The mixture showed cytotoxic activity against HeLa and T47D cell with $I_{50} 33$ and $53 \mu \mathrm{g} / \mathrm{mL}$ respectively. The extract caused cytotoxic effect through apoptotic mechanism.
\end{abstract}

Keywords: Zingiber officinale cv. Rubrum, Piper retrofractum, cytotoxic, HeLa cells, T47D cells

\section{INTRODUCTION}

World Health Organization (WHO) provides an illustration that $12 \%$ of all deaths in the world caused by cancer. Cervical carcinoma is the leading cause of cancer-related death in women [Suwiyoga, 2007]. Based on data from the Ministry of Health of the Republic of Indonesia in 2005 incidence of cervical carcinoma was second ranked after breast cancer [Anonymous, 2007]. Cancer chemotherapy are include cytostatic drugs, hormones, antihormon, and biological compounds. These drugs cause side effects because its affect to synthesis of nucleic acids and proteins, so the cancer cells and normal cells will be damaged [Stetler and Kleiner, 2001].

Research for cancer drug conducted to discover new drugs for cancer therapy. Indonesia is rich in natural ingredients, particularly plant materials, which are used empirically for cancer, including red ginger (Zingiber officinale cv. Rubrum) and java chili (Piper retrofractum).
Research has been conducted on red ginger, i.e anti-cancer activity and anti-inflammatory drug on liver cancer [Habib et al., 2008], inhibit the activity of cell growth and modulates secretion angiogenic factor in ovarian cancer cells [Rhode $e t$ al., 2007]. Research of Kim et al. [2008] showed that the red ginger rhizome have active content as a cytotoxic agent, namely oleoresin consisting of gingerol, paradol, shogaol, zingerone, resin and volatile oil which is a group of terpenoids [Ravindran et al., 2005]. 
Research in vitro and in vivo also has been conducted on piper java chili extract. Java chili has been investigated to have antioxidant activity [Jagdale et al., 2009; Wakade et al., 2008], analgesic activity, used to reduce pain in cancer [Febrina and Subarnas, 2006], and toxic effects on cells Myeloma with $\mathrm{IC}_{50}$ of $55,48 \mu \mathrm{g} / \mathrm{mL}$ [Setyorini, 2007]. As anticancer active content on the piper java fruit are alkaloids [Selvendiran et al., 2003; Pradeep and Kuttan, 2004].

Cancer treatment by combining several plants in Thailand called Pikutbenjakul done by Sakpakdeejaroen and Itharat [2009], reported to have cytotoxic activity Linn Piper chaba, Zingiber officinale, and herbal medicine Pikutbenjakul (Piper chaba Linn, Piper sarmentosum Roxb, Piper interruptum Opiz., Plumbago indica Linn. and Zingiber officinale) against breast adenocarcinoma cells (MCF-7) obtained IC $_{50}$ Piper chaba Linn, Zingiber officinale, and Pikutbenjakul of $35 ; 31$ and $33 \mu \mathrm{g} / \mathrm{mL}$, respectively.

The p53 gene appears to trigger programmed cell death (apoptosis) as a way of regulating uncontrolled cellular proliferation in the setting of aberrant growth signals [Rugo, 2006]. When cellular stress (e.g. DNA damage) occurs, proapoptotic proteins in the cytosol will be activated. As a result, cytochrome c localized in mitochondria will be released to the cytosol, activated caspase-9 [Fan et al., 2005]. The purpose of this study was to investigate the active constituent of ethanolic extract of ginger rhizome and java chili and its cytotoxic and apoptosis activity on HeLa and T47D cells.

\section{METHODS}

\section{Plant materials, chemicals, cell line and culture}

Z.offinale rhizome and P. Refractum were purchased on the local market and authenticated in taxonomy laboratory at biology Faculty Jenderal Soedirman University and stored as a voucher specimen in the same faculty. Cisplatin and tamoxifen were obtained from parasite laboratory, Faculty of Medicine, Gadjah Mada University. HeLa and T47D cells were obtained from parasite laboratory, Faculty of Medicine, Gadjah Mada University. HeLa and T47D cells were routinely cultured in RPMI 1640 medium (Sigma) supplemented with $10 \%$ Fetal Bovine Serum (FBS) (Sigma-Aldrich, USA) at $37^{\circ} \mathrm{C}$ in a $5 \% \mathrm{CO}_{2}$ atmosphere, $3 \%$ penicillin- streptomycin and $1 \%$ fungison. Subcultures were obtained after treatment with $0.05 \%$ trypsin (Gibco, Auckland) in phosphate buffered saline.

\section{Preparation of extract combination}

Red ginger and java chili washed, cut into pieces, dried and crushed into powder. 400 grams of red ginger rhizome powder, 400 grams of piper java fruit and combination of red ginger: java chili 1:1 (one each 200 gr) were extracted by maceration using $96 \%$ ethanol for $3 \times 24$ hours. The extract is filtered and then evaporated.

\section{Constituent Identification}

The extract then analysis using Thin Layer Chromatography (TLC) with silica gel $\mathrm{GF}_{254}$ stationary phase and mobile phase toluene-ethanolacetic acid (8: 2:1) for terpenoids in red ginger rhizomes and n-hexane-ethyl acetate $(3: 2)$ for alkaloid in java chili. Extracts from each sample was spotting in TLC plate, eluated with mobile phase, and sprayed with Vanillin- $\mathrm{H}_{2} \mathrm{SO}_{4}$ reagent for terpenoids and Dragendorf reagents for alkaloid. The spots were observed using UV light with wavelength $254 \mathrm{~nm}$.

\section{Preparation of the test material (stock solution)}

The ethanol extract of red ginger rhizome, Java piper, and mixtures were weighed $20 \mathrm{mg}$, then added $100 \mathrm{~mL}$ of DMSO as stock solution. The concentration of extract and cisplatin obtained from dilution with RPMI-1640 medium for the cytotoxic and apoptosis test.

\section{Cell viability assay: 3-(4,5-dimethylthiazol-2- yl)-2,5-diphenyl tetrazolium bromide (MTT) assay}

For cell viability assay, $1.5 \times 10^{4}$ cells/well were plated in $100 \mu 1$ of RPMI 1640 media. Cells were incubated overnight at $37^{\circ} \mathrm{C}$ in humidified atmosphere of $5 \% \mathrm{CO}_{2}$ for cells attachment. Extract was added at various concentrations ranging from $500 ; 250 ; 125 ; 62.5 ; 31.25 ; 15.63$; and $7.81 \mu \mathrm{g} / \mathrm{mL}$ after $24 \mathrm{~h}$ incubation. After $24 \mathrm{~h}$ incubation, $100 \mu \mathrm{L}$ MTT $(5 \mathrm{mg} / \mathrm{mL}$ in PBS) was added to the plate. The resulting MTT-products were determined by measuring the absorbance at $595 \mathrm{~nm}$ with ELISA reader. Each point represents the mean of triplicate experiments. Absorbance data then calculated to the standard curve equation of HeLa and T47D cells in order to get the number of living cells in the control cells and the number of living cells in the test cell. Inhibition percentage of each test solution is determined to obtained $\mathrm{IC}_{50}$ with probit analysis using SPSS (Statistical Product and Service Solutions). 


\section{Determination of Apoptosis}

Cells were grown on glass coverslips in tissue culture dishes (Falcon) and were allowed to attach for $24 \mathrm{hr}$ prior to the addition of drug. After the cells were incubated with drug for 24 hours, the coverslips were washed once in phosphatebuffered saline and fixed in object glass. Treated cells were stained with acridine orange and ethidium bromide $5 \mu \mathrm{L}$ and visualized by fluoresence microscopy. Viable (normal, green nuclei), early apoptotic (condensed, green nuclei) and late apoptotic (condensed, red nuclei) cells were observed.

\section{RESULTS}

The extract had active substance for its anticancer activity
Stationary phase used is silica gel GF254 plates that have been coated with compounds that can berflouresens at wavelength $254 \mathrm{~nm}$. Mobile phase used was a mixture of toluene-ethanol-acetic acid with a ratio of 8: 2: 1 for identification of terpenoids on red ginger rhizome extracts. From the TLC image of red ginger rhizome extract (Figure 1), after sprayed with vanillin-sulfuric acid reagent and then heated at $1000 \mathrm{C}$ for 10 minutes in visible light there was red purple spots. Further observation under UV 254 gained 3 spots. Patches of red ginger rhizome on UV 254 reduction is not too clear. The first spots of purple red indicates that the red ginger rhizome extract contains terpenoids.

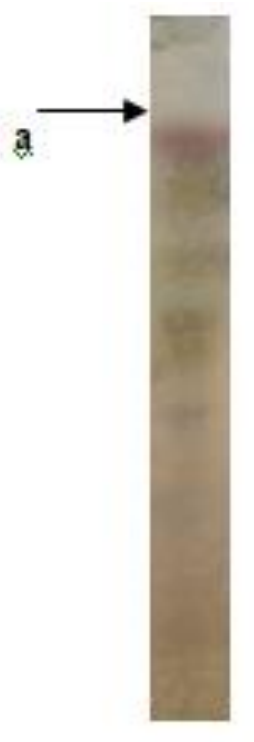

A

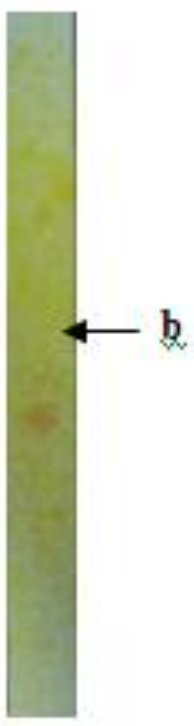

B

Figure I. Thin Layer Chromatography. Stationary phase: Gel Silica $\mathbf{G}_{254}$, Mobile phase: A. toluene-ethanolacetic acid (8:2:I) sprayed with Vanillin-H2SO4 reagent (red purple spot-a)), B. n-hexane-ethyl Acetate (3:2) sprayed with dragendorf reagent (brown-orange spot-b)

Mobile phase mixture of n-hexane and ethyl acetate with a ratio of $3: 2$ is used for identification of alkaloids in the fruit extract of cayenne Java. Observation under UV light 254 seen seven spots and sixth spots appear orange.

\section{Extract combination had cytotoxic activity on HeLa and T47D Cell Lines}

Figure 2a. showed increased concentrations of the test material causes an increase in the percentage inhibition of Hela cell growth. At a concentration of $62.5 \mathrm{ug} / \mathrm{mL}$, red ginger rhizome extract, Java piper, and a mixture capable to inhibit the growth 
of HeLa cells at $65 \%, 58 \%$ and $77 \%$. Cisplatin has the inhibition on the growth of HeLa cells at a concentration of $15 \mathrm{ug} / \mathrm{mL}$ of $91 \%$.

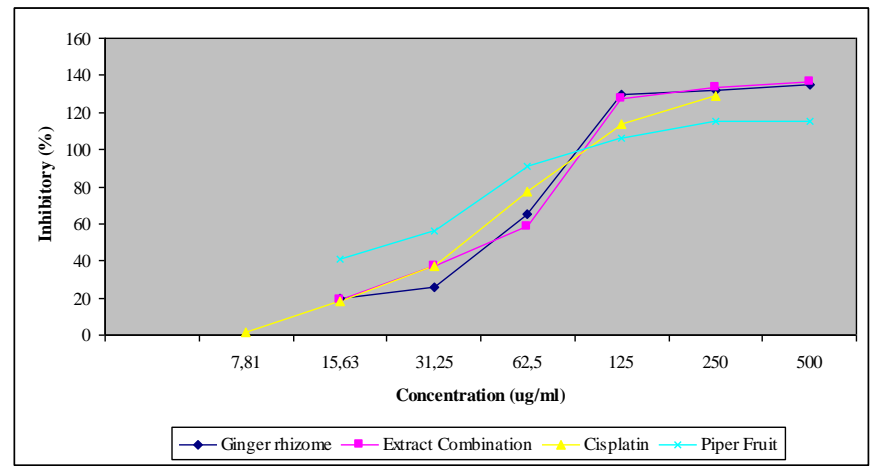

(a)

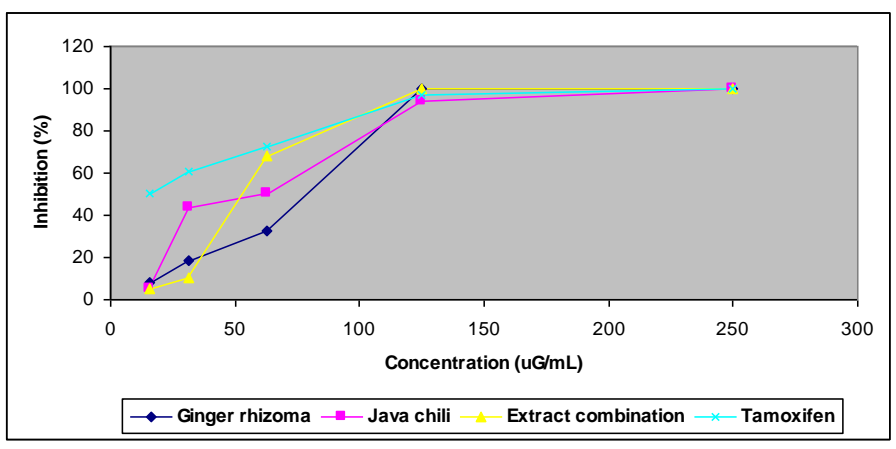

(b)

Figure 2. Inhibition rate on HeLa (a) and T47D (b) cell line by ginger rhizome, java chili, extract combination, tamoxifen and cisplatin. HeLa and T47D cells were treated with various doses of ginger rhizome, java chili, extract combination, tamoxifen and cisplatin, incubated for 24 hours at $37 \circ \mathrm{C}$ in humidified $5 \% \mathrm{CO} 2$ atmosphere. Cell viability was determined by MTT assay, absorbance was read at $595 \mathrm{~nm}$. Inhibition rate (\%) was defined as: ((live cell in the control - live cell in the test group)/live cell in the control) $x 100$. Standard curve: $y=0.00001 \times+$ $0.207\left(R^{2}=0.927\right)$ for HeLa cells and $y=0.0000 I x+0.34 I I$ for T47D cells $\left(R^{2}=0.9906\right)$. Results are average of three independent experiments (mean $\pm S D$ ).

Figure $2 \mathrm{~b}$. showed increased concentrations of the test material causes an increase in the percentage inhibition of T47D cell growth. At a concentration of $62.5 \mathrm{ug} / \mathrm{mL}$, red ginger rhizome extract, Java piper, and a mixture capable to inhibit the growth of T47D cells at $32 \%, 47 \%$ and $62 \%$.
Cisplatin has the inhibition on the growth of T47D cells at a concentration of $15 \mathrm{ug} / \mathrm{mL}$ of $90 \%$.

Figure 3. showed that the material has the ability to reduce the growth of cells as shown by the $\mathrm{IC}_{50}$ value. Mixture of red ginger rhizome extracts and Java chili (1:1) has a $\mathrm{IC}_{50}$ of $33 \mathrm{ug} / \mathrm{mL}$ in Hela cells and $68 \mathrm{ug} / \mathrm{mL}$ in T47D cells. 


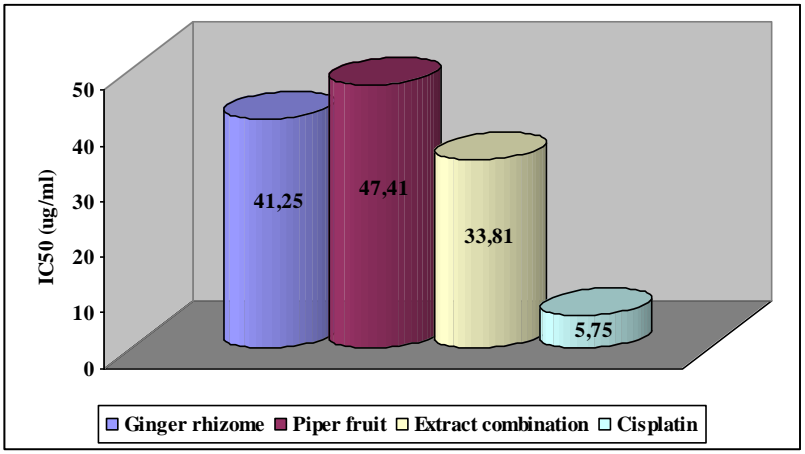

(a)

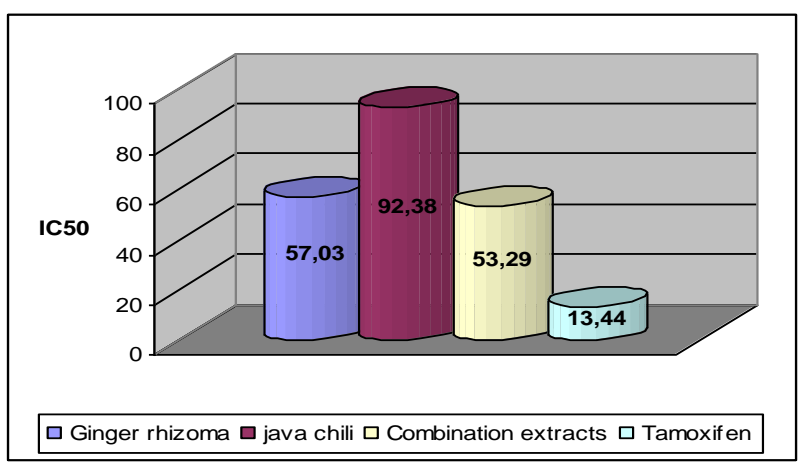

(b)

Figure 3. IC 50 of ginger rhizome, java chili, extract combination, tamoxifen and cisplatin on HeLa (a) and T47D (b) cancer cells. Concentrations inhibiting $50 \%$ of the cell were determined by probit analysis using SPSS software.

\section{Extract combination induced apoptosis}

Cells treated with extract combination with $\mathrm{IC}_{50}$ dosis, underwent the classical and colour changes indicate of apoptosis. 


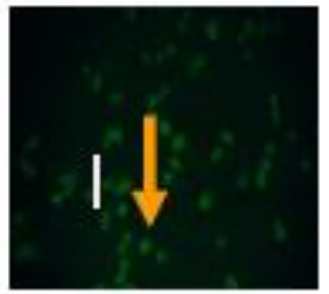

(a)

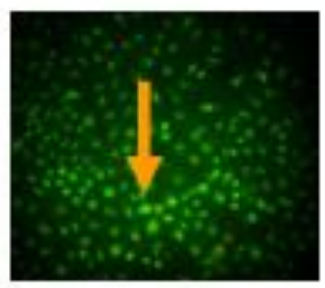

(c)

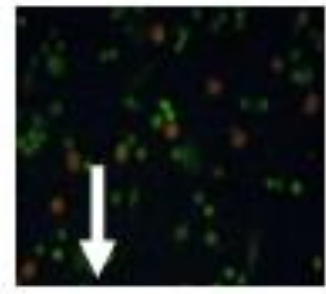

(b)

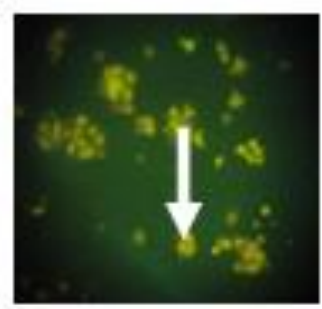

(d)

Figure 4. Hela $(a, b)$ and T47D $(c, d)$ cells were treated with acridine orange and ethidium bromide. Viable cell (orange arrow), apoptotic cell (white arrow). Cells treated with extract combination (ginger rhizome: java chili = I:I) with $\mathrm{IC}_{50}$, underwent the classical and colour changes indicate of apoptosis.

\section{DISCUSSION}

Identification of chemical constituents of red ginger and java chili extracts conducted to determine the active compounds which efficacious for cancer. The study reported that terpenoids from extracts of red ginger rhizome and alkaloids of java chili had potential effect as anticancer [Shukla et al., 2007; Selvendiran et al., 2003]. Silica gel $\mathrm{GF}_{254}$ was used as stationary phase. According to Stahl [1985], silica gel has a moisture that significantly affected the separation power. Toluene-ethanol-acetic acid (8: 2: 1) was used as mobile phase for identification of terpenoids on red ginger extract. Toluene $\left(\mathrm{C}_{7} \mathrm{H}_{8}\right)$ has a dielectric constanta 2.3, so will dissolve non polar compounds. Acetic acid was a polar solvent which has a dielectric constanta 6.2 may dissolve polar compounds such as inorganic salts and organic compounds. While ethanol has a dielectric constanta 24.3, more polar than acetic acid. Oleoresin in red ginger included in the group of terpenoids that expected to be able to separate with mobile phase.

Results after sprayed with vanillin-sulfuric acid reagent and then heated at $100^{\circ} \mathrm{C}$ for 10 minutes to accelerate the reaction formation and intensity of the spot color [Rohman, 2009]. In visible light visible there was purple-red spots. Further observation under UV light 254 obtained three spots. According to Stahl [1985], spots of red-violet color spot of red ginger is zingeron.

Mobile phase mixture of n-hexane and ethyl acetate with a ratio of 3: 2 are used for identification alkaloids in extracts java chili. Dielectric constanta of n-hexane and ethyl acetate successively are 1.890 and 6.02. N-hexane is more nonpolar than ethyl acetate which is semipolar. The selection phase was based on active compounds namely alkaloids piperine which that are semipolar. Therefore, with similar levels of polarization as this makes the greater separation of substances [Stahl, 1985]. Dragendorff reagent (potassium tetraiodobismutat or $\mathrm{BI}_{3} \mathrm{KI}$ ) was a 
reagent which bind to the electron on $\mathrm{N}$ atom of the alkaloid. Observation under UV light 254 seen seven spots and sixth spots appear orange According to the theory proposed by Wagner and Bladt [1995] stated that the positive results of alkaloids with Dragendorff reagent spray, brown or orange. With the existence of six orange spots showed that java chili extract contains alkaloids.

Figure 2. showed that the material has a ability to inhibit HeLa and T47D cell growth as shown by the $\mathrm{IC}_{50}$ value. This indicates that the combination has cytotoxic activity against $\mathrm{HeLa}$ cells. Meyer et al. [1982] declares an extracts said to have anticancer activity if the $\mathrm{IC}_{50}$ value of less than $1000 \mu \mathrm{g} / \mathrm{mL}$ after 24 hours of contact time. $\mathrm{IC}_{50}$ is concentration that can inhibit cell growth by $50 \%$ cell line. The smaller the $\mathrm{IC}_{50}$ of a compound the more toxic compound it was [Doyle and Gaffiths, 2000].

Merging or combining several plants in cancer treatment performed to enhance the cytotoxic activity and minimize side effects caused by the use of anticancer drugs [Beinfield, 2005]. Cytotoxic activity of extract combination against HeLa cells was higher with an $\mathrm{IC}_{50}$ value of 33.807 compared with $\mathrm{IC}_{50}$ values of each extract, i.e 41.249 and $47.409 \mu \mathrm{g} / \mathrm{mL}$ for red ginger rhizome and piper java fruit extracts. This is because of red ginger and piper java fruit has a different mechanism against cancer. Red ginger rhizome could raise natural killer cell activity (NK) to lisis target cells, namely tumor cells and virus-infected cells [Zakaria et al., 1999] and is able to inhibit the activity of NFkB (Nuclear Factor kappa B) through the inhibition of cytokine pro inflammation, so the emergence of inhibit TNF- $\alpha$ which is the cause of the emergence of tumors [Habib et al., 2008; Hudson et al., 2000]. Piperine contained in piper java fruit protect cells from cancer by binding proteins in the mitochondria to trigger apoptosis without harming normal cells through enhanced activity of antioxidant enzymes like superoxide dismutase, catalase and glutathione peroxidase [Selvendiran et al., 2003]. Additionally, piperine may inhibit NFKB thereby preventing the formation of tumors through TNF-, so angiogenesis does not occur [Pradeep and Kuttan, 2004]. Given the different mechanism of action following the combination of plants can enhance the cytotoxic activity.

Red ginger rhizome extracts had $\mathrm{IC}_{50}$ values up to $41.249 \mu \mathrm{g} / \mathrm{mL}$ less than the piper java fruit extract of chili java $47.409 \mu \mathrm{g} / \mathrm{mL}$. Differences in mechanism of action against cancer cells affect the cytotoxic activity. Research carried out by Rhode et al. [2007] showed that the red ginger can inhibit cell growth and modulates secretion angiogenic factor in ovarian cancer cells. Therefore, a potential red ginger in the treatment and prevention of ovarian cancer. Another study carried out on liver cancer and metastases by inhibiting activation of CD8 $+\mathrm{T}$ cells [Habib et al., 2008; Suzuki et al., 1997]. Red ginger able to minimize the side effects of cancer drugs such as nausea and vomiting [Ernst and Pittler, 2000].

Piper java fruit extract in this study have cytotoxic activity against $\mathrm{HeLa}$ cells with $\mathrm{IC}_{50}$ of $47.409 \mu \mathrm{g} / \mathrm{mL}$. This showed that $96 \%$ ethanol extract of piper java fruit has cytotoxic activity against HeLa cells was better than the $70 \%$ ethanol extract of chilies java [Suhartatik, 2008]. In addition, cytotoxic activity against HeLa cell of piper java fruit extracts better than against myeloma cells. This is shown by $\mathrm{IC}_{50}$ values of piper java fruit against HeLa cells are smaller than the myeloma cells that is $46.246 \mu \mathrm{g} / \mathrm{mL}$ and 55.48 $\mu \mathrm{g} / \mathrm{mL}$. This difference in the chances of having the target compounds and causes of action of cancer cells in HeLa cells and myeloma cells. The study by Choi et al. [2009] showed that the piper fruit can reduce the risk of cisplatin resistance of cancer cells by induction of apoptosis via heme oxygenase-1 (HO-1). Cisplatin has the smallest $\mathrm{IC}_{50}$ value of $5.745 \mu \mathrm{g} / \mathrm{mL}$. It showed better cytotoxic activity of cisplatin against HeLa cells. Based on the National Comprehensive Cancer Network (NCCN) Clinical Practice Guidelines in Oncology, cisplatin is the first-line monotherapy in the treatment of cervical cancer [Teng et al., 2004].

Ginger extract at increasing concentrations induced apoptosis dose dependently in colon cancer cells [Abdullah et al., 2010]. [6]-gingerol associated with the modulation of p53 and involvement of mitochondrial signaling pathway in $\mathrm{B}$ [a]P-induced mouse skin tumorigenesis [Nigam et al., 2009].

Java chilli fruit extract protects cells from cancer by binding proteins on cancer cell mitochondria to trigger apoptosis without damaging the surrounding cells through increased activity of antioxidant enzymes like superoxide dismutase, catalase and glutathione peroxidase [Selvendiran et al., 2003]. In addition, chilies java can inhibit $\mathrm{NF \kappa B}$, inhibit tumor formation by TNF- $\alpha$ that resulted in no occurrence of angiogenesis [Pradeep and Kuttan, 2004].

\section{CONCLUSION}

Zingiber officinale cv. Rubrum had terpenoids, while Piper retrofractum had alkaloids 
substance. The mixture showed cytotoxic activity against HeLa and T47D cell with $\mathrm{IC}_{50} 33.807$ and $53.289 \mu \mathrm{g} / \mathrm{mL}$ respectively. The extract caused cytotoxic effect through apoptotic mechanism.

\section{REFERENCES}

Abdullah, S., Abidin, S.A.Z., Murad, N.A., Makpol, S., Ngah, W.Z.W. and Yusof, Y.A.M., 2010, Ginger Extract (Zingiber officinale) Triggers Apoptosis and G0/GI Cells Arrest in HCT I 16 and HT 29 Colon Cancer Cell Lines, African Journal of Biochemistry Research, 4(4), 134- 142.

Anonymous, 2007, Indonesia Health Profile 2005, 70, Departemen Kesehatan Republik Indonesia, Pusat Data Kesehatan, Jakarta.

Beinfield, H. and Kornglod, E., 2005, Chinese Medicine and Cancer Care, Alternative Therapies, Sept/Oct, 9, 5, 38-52.

Choi, B., S. Kim, T. Park, G. Li, S. Park, R. Park, B. Chung, B. Kim, 2009, Piperine Protects Cisplatin-Induced Apoptosis Via HemeOxygenase-I Induction in Auditory Cells, The Journal of Nutritional Biochemistry, I8, Issue 9, 615-622

Doyle, A. and Griffiths, J.B., 2000, Cell and Tissue Culture for Medical Research, 47, John Willey and Sons, Ltd., New York.

Ernst, E. and Pittler, M.H., 2000, Efficacy of Giner for Nausea and Vomiting: A Systematic Review of Randomized Clinical Trial, $\mathrm{Br} J$ Anaesth, 84, 125-132.

Fan, T.J., Han, L.H., Cong, R.S. and Liang, J., 2005, Caspase Family Proteases and Apoptosis, Acta Biochimica et Biophysica Sinica, 37(II), 719-727.

Febrina, E. and Subarnas, A., 2006, Aktivitas Analgesik Fraksi Alkaloid Buah Cabe Jawa (Piper retrofractum Vahl.) pada Mencit, Jurnal Ilmiah Farmasi Indonesia UNPAD, 4(I), Jatinangor, Sumedang.

Habib, S.H.M., Makpol, S., Hamid, N.A.A., Das, S., Ngah, W.Z.W. and Yusof, Y.A.M., 2008, Ginger Extract (Zingiber Officinale) has AntiCancer and Anti-Inflammatory Effects on Ethionine-Induced Hepatoma Rats, Clinics, 63(6), 807-813.

Hudson, S., DeGuzman, A., Bucana, C.D. and Fidler, I.J., 2000, Nucler Factor-kappa B Activity Correlates With Growth, Angiogenesis, and Metastasis of Human Melanoma Cells in Nude Mice, Clin Cancer Res., 6, 2573-258I.
Jagdale, S.C., Kuchekar, B.S., Chabukswar, A.R., Lokhande, P.D. and Raut, C.G., 2009, AntiOxidant Activity of Piper longum Linn., International Journal f Bilogical Chemistry, 3(3), II9-125.

Kim, J.S., Lee, S.I., Park, H.W., Yang, J.H., Shin, T.Y., Kim, Y.C., Baek, N.I., Kim, S., Choi, S.U., Kwon, B.M., Leem, K.H., Jung, M.Y. and Kim, D.K., 2008, Cytotoxic Components from the Dried Rhizomes of Zingiber officinale Roscoe, Arch Pharm Res, 3 I (4), 4 I 5-4 I 8.

Meyer, B.N., Ferigni, N.R., Putnam, J.E., Cobsen, L.B., Nichols, D.E. and McLaughlin, J.L., 1982, Brine Shrimp: A Conventient General Bioassay for Active Plant Constituent, Planta Medica, 45, 3I-45.

Nigam, N., George, J., Srivastava, S., Roy, P., Bhui, K., Singh, M. and Shukla, Y., 2009, Induction of apoptosis by [6]-gingerol associated with the modulation of p53 and involvement of mitochondrial signaling pathway in $\mathrm{B}[\mathrm{a}] \mathrm{P}$ induced mouse skin tumorigenesis, Cancer Chemotherapy and Pharmacology, 65, 687696.

Pradeep, C.R. and Kuttan, G., 2004, Piperine is a Potent Inhibitor of Nuclear Factor-KappaB (NF-kappaB), c-Fos, CREB, ATF-2 and Proinflammatory Cytokine Gene Expression in Bl6F-10 Melanoma Cells, Int Immunopharmacol, 4( I4), I795-I803.

Ravindran, P.N. and Babu, K.N., 2005, Ginger The Genus Zingiber. CRC Press. New York.

Rhode, J., Fogoros, S., Zick, S., Wahl, H., Griffith, K.A., Huang, J. and Liu, R., 2007, Ginger Inhibits Cell Growth and Modulates Angiogenic Factors in Ovarian Cancer Cells, BMC Complementary and Alternative Medicine, 7(44), I-9.

Rohman, A., 2009, Kromatografi untuk Analisis Obat, 52-53, Graha Ilmu, Yogyakarta.

Rugo, H.S., 2006, Cancer in Current Medical Diagnosis and Treatment. $45^{\text {th }}$ Edition, Eds. Tierney, Lawrence M., McPhee, Stephen J., Papadakis, Maxie A., McGraw-Hill, Publishing Company, New York, USA.

Sakpakdeejaroen, I. and Arunporn, I., 2009, Cytotoxic Compounds Against Breast Adenocarcinoma Cells (MCF-7) from Pikutbenjakul, Journal Health Res, 23(2), 7I76.

Selvendiran, K., Singh, J.P., Krishnan, K.B. and Sakthisekaran, D., 2003, Cytoprotective Effect of Piperine Against Benzo[a]pyrene Induced Lung Cancer with Reference to 
Lipid Peroxidation and Antioxidant System in Swiss Albino Mice, Fitoterapia, 74(I-2), $109-15$.

Setyorini, 2007, Uji Sitotoksik Ekstrak Etanol 70\% Buah Cabe Jawa (Piper retrofractum Vahl.) terhadap Sel Myeloma, Skripsi, Universitas Muhammadiyah Surakarta, Solo.

Stetler, S.W.G. and Kleiner, D.E., 200I, Molecular Biology of Cancer : Invasion and Metastases in Cancer Principle \& Practice of Oncology, $6^{\text {th }}$ Ed., Eds. DeVita, V.T., Hellman, S., dan Rosenberg, S.A., 91-I02, Lipicott Williams \&Wilkins, Philadelphia, USA.

Shukla, Y., Prasad, S., Tripathi, C., Singh, M., George, J. and Kalra, N., 2007, In vitro and in vivo modulation of testosterone mediated alterations in apoptosis related proteins by [6]-gingerol, Molecular Nutrition \& Food Research, 5 I (I2), I 492-1502.

Stahl, E., 1985, Analisis Obat secara Kromatografi dan Makroskopi, 7-15, 198-199, 205-213, Penerbit ITB, Bandung.

Suhartatik, 2008, Uji Sitotoksik Ekstrak Etanol 70\% Buah Cabe Jawa (Piper retrofractum Vahl.) Terhadap Sel HeLa, Skripsi, Universitas Muhammadiyah Surakarta.

Suwiyoga, I.K., 2007, Kanker Serviks: Penyakit Keganasan Fatal Yang dapat Dicegah, Journal Obstetri Ginekologi Indonesia, 3 I, I.

Suzuki, F., Kobayashi, M., Komatsu, Y., Kato, A. and Pollard, R.B., 1997, Keishi-Ka-Kei-To, A
Traditional Chinese Herbal Medicine, Inhibits Pulmonary Metastase of BI6 Melanoma, Anticancer Res, 17, 873-878.

Teng, N., Abu, N.R., Bahador, A., Bristow, M.A.R.E., Campos, S., Cho, K.R., Copeland, L., Eifel, P., Fiorica, J., Greer, B.E., Kapp, D.S., Kavanagh, J., Koh, W.J., Kuettel, M., Lurain, J.R., Molpus, K.L., Nag, S., Partridge, E.E., Powell, C.B., Reynolds, R.K., Small, W.J., Soper, J. and Tillmanns, T.D., 2004, Cervical Cancer Guidelines Clinical Practice Guidelines in Oncology, J Natl Compr Canc Netw, 6(2), 612-630.

Wakade, A.S., Shah, A.S., Kulkarni, M.P. and Juvekar, A.R., 2008, Protective Effect of Piper Longum L. on Oxidatife Stress Induced Injury and Cellular Abnormality in Adriamycin Induced Cardiotoxicity in Rats, Indian Journal of Experimental Biology, 46, 528-533.

Wagner, H. and Bladt, S., 1995, Plant Analysis a Thin Layer Chromatography Atlas, 292-293, 360, 364, Springer Verlag, Berlin.

Zakaria, F.R. and Rajab, T.M., 1999, Pengaruh Ekstrak Jahe (Zingiber officinale Roscoe) terhadap Produksi Radikal Bebas Makrofag Mencit sebagai Indikator Imunostimulan secara In Vitro, dalam Prosiding Seminar Nasional Teknologi Pangan Persatuan Ahli Pangan Indonesia (PATPI), 707-7I6. 